\title{
Effect of Different Planting Methods on Yield and Economics of Cultivation of Maize
}

\author{
Subhash Chandra ${ }^{{ }^{*}}$ and Mritunjay Kumar ${ }^{2}$ \\ ${ }^{1}$ Department of Farm Machinery, C.A.E., Pusa, India \\ ${ }^{2}$ Department of Agronomy (Maize), T.C.A., Dholi, Dr. Rajendra Prasad Central Agricultural \\ University, Bihar, Pusa (Samastipur) - 848125, India \\ *Corresponding author
}

\section{A B S T R A C T}

\section{Keywords}

Maize, Double fork dibbler, Bed planting, Growth rate, Yield,

Productivity,

Profitability

Article Info

Accepted:

12 November 2019

Available Online:

10 December 2019
A high yielding variety Shaktiman-5 was grown in farmer's field in Rabi2015 under different planting methods. Maize seeds were planted in flat and also on bed by khurpi as well as by Chinese double fork dibbler. In general, planting of maize on bed provided 12-20\% more yield than the flat planting. However, there was only a marginal gain in yield of maize (4-9\%) with use of double fork dibbler due to placement of fertilizer quite closer to seed. Further, use of dibbler increased planting capacity of manual labour and a saving of about 13 mandays/ha attributing to saving of Rs. 3250/ha in planting cost was recorded. The use of dibblers for flat and bed planting was found to be profitable by amount Rs. 6850/ha and Rs. 9650/ha, respectively, which advocates the use of dibbler as improved planting tool for small and marginal farmers of Bihar.

\section{Introduction}

Maize (Zea mays L.) is one of the staple food grains after rice and wheat. It is grown in 7.08 lakh hectares in Bihar and has registered productivity of 3.5 tonne/ha. Maize is grown all around the year with highest productivity (3.6 tonne/ha) in Rabi season (Anonymous, 2015-16). Its cultivation is highly dominated by costly hybrid seeds and planting method. Inappropriate planting method caused reduction in germination, growth and development and increased susceptibility to disease and lodging (Bakht et al., 2011). Furthermore, the degree of soil compaction, soil bulk density and soil moisture conditions are important factors which influence seedling emergence and crop yield. Improvement in planting techniques for suitable seed bed preparation has also been suggested in order to ensure good stand establishment and optimum plant population (Butter et al., 2006). 
Conventional flat sowing of maize has a number of disadvantages including reduced water productivity and leaching of nutrients. Soil surface crusting developed in flood irrigated flat sown maize reduced seed germination and seedling emergence (Bakht $e t$ al., 2006). Alike ridge sowing, bed planting methods has advantages over flat sowing. Amin et al., (2006) reported higher growth and yield of maize in ridge sowing than flat sowing. Bed planting resulted in reduce soil compaction and easy management of soil residue and gave higher crop growth rate as compared to ridge sowing (Verhulust et al., 2011). Further, Ortega et al., 2008 has also reported that raised bed planting is the most efficient method of planting for wheat, maize and other crops.

Bed planting methods saves irrigation water. It has been reported that wheat and maize are planted in many parts of the world on beds. Bed planting on an average saved 29\% of water as compared to flat beds (Naresh et al., 2011).

In spite of overall growth of mechanization in Bihar, sowing of maize is still done manually by majority of farmers with traditional hand tools i.e. khurpi under flat sowing. The poor adoption of tractor operated costly maize planters by small and marginal farmers may be either because of their poor socio-economic condition or because of lack of optimum performance of such machines in small plots.

The use of double fork dibblers with multiple seed rollers on raised bed may be of great use for small farmers, who can not afford costly large sized tractor operated planters.

Therefore, in view of the need to promote mechanization in maize planting operation among small and marginal farmers, the experiment was planned to assess the comparative performance of double fork manually operated dibblers vis-à-vis khurpi on yield and economics of maize cultivation both for flat sowing and raised bed planting situation.

\section{Materials and Methods}

The experiment was conducted in Rabi-2015 in farmer's field of Malinagar village with five replications of each treatment. The different sowing methods were adopted for sowing of hybrid maize variety, Shaktiman-5.

The first treatment $\left(\mathrm{T}_{1}\right)$ was sowing of maize by traditional hand tool 'khurpi' in flat land after proper tillage and preparation of seed bed as it is widely practiced by the farmers of Bihar. Further, maize was planted on flat surface after proper tillage by using manually operated 'double fork dibbler' as treatment $\mathrm{T}_{2}$.

The dibbler was consisting of two compartments, one for seed and another for fertilizer. Under treatment $T_{3}$ and $T_{4}$, maize seeds were planted on raised bed prepared by tractor operated bed former by 'khurpi' and 'double fork dibbler', respectively.

Before use of seeding tools, the field was prepared by operating tractor operated M. B. Plough in one pass followed by three passes of Disc Harrow and one pass of Rotavator.

In order to achieve the good and proper bed, the weeds were collected and removed from the field. At the time of sowing, bulk density of soil was measured by using core ring method as suggested by Blake and Hartage and its value was $1.32 \mathrm{~g} / \mathrm{cm}^{3}$.

The maize was sown using randomized block design (RBD) of experiment on 26.10.2015 and was harvested on 12.04.2016. The fertilizers $\mathrm{N}, \mathrm{P}$ and $\mathrm{K}$ were added in ratio of 150:75:50 in plots with treatment $T_{1}$ and $T_{3}$, phosphorous and potash were added as basal 
dose after tillage and before planking. However, in treatment $\mathrm{T}_{2}$ and $\mathrm{T}_{4}, 10 \%$ of total phosphorous was utilized through double fork dibbler and rest as basal dose similar to the treatment $T_{1}$ and $T_{3}$. Nitrogen was applied as per normal practice in split dose.

Measurement of daily working (field capacity) of khurpi and dibbler was done by measuring total area covered divided by total measured time of operation.

The other performance indicating parameters were evaluated as per standard formula described below:

\section{Measurement of bulk density}

Bulk density of experimental plot was measured by using core sampler. The core sampler was driven into the soil with the help of hammer until the soil reaches to the top of core cutter.

The weight of core cutter with soil was weighed and bulk density was calculated as per formula given below:

$$
\text { Bulk density }(\mathrm{D})=\frac{W_{2}-W_{1}}{\pi \frac{d^{2}}{4} h}
$$

Where,

$\mathrm{W}_{1} \quad=$ weight of empty core cutter, gm

$\mathrm{W}_{2} \quad$ = weight of cutter with soil, gm

$\mathrm{d}=$ internal diameter of core sampler, $\mathrm{cm}$

$\mathrm{h} \quad=$ height of core sampler, $\mathrm{cm}$

$\pi \quad=3.14$

Bulk density is expressed in unit, $\mathrm{g} / \mathrm{cm}^{3}$

\section{Field capacity}

It was measured by formula,

Field capacity $=$ Area covered $/$ time to cover that area

It is expressed unit 'ha/h'. The field capacity of dibbler and khurpi was computed on days basis of eight hours and in unit 'ha/day'.

\section{Calculation of mandays}

The time of operation of equipment under field condition was calculated from the field capacity of equipments by using formula

Time to cover the field $=1 /$ field capacity.

The field capacity measured in unit 'ha/day' will directly provide the time of equipment operation in days. umber of mandays represents manhour for 8 hours/day.

\section{Plant height}

It was recorded using measuring tape. Plant height was measured from bottom to top of maize plant except tassels at physiological maturity stage.

\section{Yield and related traits}

Final grain yield and yield contributing attributes like number of cobs per plant, number of grains per cob, 1000 grain weight were computed on harvesting and total yield under different replications of each treatment was measured.

\section{Economics of different treatments}

On the basis of cost of operation of planting equipments, tractor operated bed former, cost of seed and price of maize grain; economics of different treatments were assessed. Further, yield enhancement under bed planting system 
with use of 'double fork dibbler' was also calculated in order to assess the economics of the system.

\section{Results and Discussion}

The planting methods of any crop affects its yield and thereby the economics of cultivation. The yield parameter is evaluated on the basis of yield related traits such as number of plants/ha, number of cobs/ha, number of grains/cob, thousand grain weight etc.

The results obtained from the experiment in respect of hybrid Rabi maize variety Shaktiman-5 under different planting system is presented in table 1, 2, 3 and 4 .

\section{Plant height}

Plant height is one of the important yield related traits to be measured under any research work related to crop production. The data related to plant height under different treatments is presented in Table 1.

From perusal of data, for 30, 45, 60 and 75 days after sowing (DAS), it is evident that under flat planting condition, the crop planted with dibbler registered higher plant growth for all intervals of data recording time.

In treatment $T_{3}$, where maize was planted manually with khurpi on bed, plant height for all observation duration were more than the treatment $\mathrm{T}_{1}$ and $\mathrm{T}_{2}$.

The treatment $\mathrm{T}_{4}$ had taller plants than all other treatments for 30, 45, 60 and 75 DAS. Higher plant growth in treatment $T_{2}$ was probably because of the special configuration of dibbler, which facilitates phosphoric fertilizer application quite closer to the seeds and thereby, the fertilizer use efficiency gets increased. In treatment $T_{3}$ and $T_{4}$, plant height was better than treatment $T_{1}$ and $T_{2}$ and that is only because of the benefits of bed planting system, which adds the plants with better availability of nutrients, water, sunlight and air besides less compacted root zone and better upward movement of soil nutrients under unsaturated soil moisture condition. The combined effect of bed planting system and placement of fertilizer quite closer to the seed accounted by the dibbler may be the reasons of highest plant growth in treatment $\mathrm{T}_{4}$.

\section{Yield}

Yield is one of the important parameter for deliberation of outcome of any experiment. It is computed and worked out based on the observations recorded in respect of number of cob/ha, number of grains/cob, thousand grain weight etc. The yield recorded under different treatments in the study has been presented in Table 2.

The data indicates that in treatment $\mathrm{T}_{2}$, where maize was planted by double fork dibbler in flat soil, number of grains/ cob and thousand grain weight, both were more than the treatment $T_{1}$. This increase is definitely on account of closer placement of fertilizer to the seed by the double fork dibbler in treatment $\mathrm{T}_{2}$, whereas, in treatment $\mathrm{T}_{1}$, phosphoric fertilizer was applied as basal dose only after tillage and before planking.

In treatment $T_{3}$ and $T_{4}$, there are gradual increase in number of grains per cob and thousand grain weight resulting into higher grain yield in both above treatments as compared treatment $T_{1}$ and $T_{2}$.

In treatment $T_{3}$, the benefits of bed planting system appears to be accountable for enhancement in yield. However, in treatment $\mathrm{T}_{4}$, combine effect of planting system and improved planting/ sowing equipment (dibbler) might be the main reason for highest productivity of maize crop. 
Table.1 Plant height in different treatments at different time intervals $(\mathrm{cm})$

\begin{tabular}{|c|c|c|c|c|}
\hline Treatments & 30 DAS* & 45 DAS* $^{*}$ & 60 DAS* $^{*}$ & 75 DAS* \\
\hline$T_{1}$ & 17.7 & 36.5 & 65.7 & 98.2 \\
\hline $\mathbf{T}_{2}$ & 19.3 & 35.8 & 67.1 & 100.7 \\
\hline $\mathbf{T}_{3}$ & 19.5 & 37.6 & 64.8 & 99.6 \\
\hline $\mathbf{T}_{4}$ & 23.2 & 38.9 & 68.3 & 104.5 \\
\hline
\end{tabular}

*Data under different treatments are mean value of five replications

Table. 2 Crop yield under different treatments

\begin{tabular}{|c|c|c|c|c|c|c|}
\hline Treatments & Cobs/m & $\begin{array}{c}\text { Cobs/ha, } \\
\mathbf{0 0 0}\end{array}$ & $\begin{array}{c}\text { No. of } \\
\text { grains/ } \\
\text { cob }\end{array}$ & $\begin{array}{c}\text { 1000 grain } \\
\text { weight, } \\
\text { gm }\end{array}$ & $\begin{array}{c}\text { Grain } \\
\text { yield } \\
\text { (q/ha) }\end{array}$ & $\begin{array}{c}\text { Increase/ decrease in } \\
\text { yield/ha over farmer's } \\
\text { practice (\%) }\end{array}$ \\
\hline $\mathbf{T}_{\mathbf{1}}$ & 8.4 & 84000 & 467 & 239 & 93.75 & - \\
\hline $\mathbf{T}_{\mathbf{2}}$ & 8.2 & 82000 & 487 & 244 & 97.44 & $\mathbf{0 3 . 9 4} \uparrow$ \\
\hline $\mathbf{T}_{\mathbf{3}}$ & 8.6 & 86000 & 498 & 245 & 104.93 & $\mathbf{1 1 . 9 2 \uparrow}$ \\
\hline $\mathbf{T}_{\mathbf{4}}$ & $\mathbf{8 . 4}$ & $\mathbf{8 4 0 0 0}$ & $\mathbf{5 4 3}$ & $\mathbf{2 4 6}$ & $\mathbf{1 1 3 . 2 4}$ & $\mathbf{2 0 . 7 8} \uparrow$ \\
\hline
\end{tabular}

Table.3 Field capacity and cost of operation of manually operated planting equipments

\begin{tabular}{|c|c|c|c|c|c|c|c|}
\hline \multirow{2}{*}{ 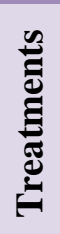 } & \multicolumn{2}{|c|}{$\begin{array}{l}\text { Cost of use } \\
\text { excluding } \\
\text { manpower } \\
\text { (Rs./ha) }\end{array}$} & \multirow[t]{2}{*}{$\begin{array}{c}\text { Field } \\
\text { capacity } \\
\text { (ha/day) }\end{array}$} & \multirow[t]{2}{*}{$\begin{array}{l}\text { No. of } \\
\text { mandays } \\
\text { labour/ha }\end{array}$} & \multirow[t]{2}{*}{$\begin{array}{c}\text { Labour } \\
\text { cost (@ } \\
\text { Rs. } \\
\text { 250/day) }\end{array}$} & \multirow[t]{2}{*}{$\begin{array}{l}\text { Labour cost } \\
\text { saving on use } \\
\text { of dibbler } \\
\text { (Rs./ha) }\end{array}$} & \multirow[t]{2}{*}{$\begin{array}{l}\text { Cost of use of } \\
\text { planting } \\
\text { equipment } \\
\text { (Rs./ha) }\end{array}$} \\
\hline & Name & Cost & & & & & \\
\hline $\mathbf{T}_{1}$ & Khurpi & 5.00 & 0.042 & $23.81 \cong 24$ & 6000.00 & - & 6005.00 \\
\hline $\mathbf{T}_{2}$ & Dibbler & 34.00 & 0.092 & $10.87 \cong 11$ & 2750.00 & 3250.00 & 2784.00 \\
\hline $\mathbf{T}_{3}$ & Khurpi & 5.00 & 0.058 & $17.24 \cong 17$ & 4250.00 & - & 4255.00 \\
\hline $\mathbf{T}_{4}$ & Dibbler & 34.00 & 0.051 & $19.61 \cong 20$ & 5000.00 & (-) 750.00 & 5034.00 \\
\hline
\end{tabular}

Table.4 Economics of maize cultivation under different treatments

\begin{tabular}{|c|c|c|c|c|c|c|c|c|}
\hline \multirow{2}{*}{ 芯 } & \multirow{2}{*}{$\begin{array}{l}\text { Cost of use } \\
\text { of } \\
\text { equipment } \\
\text { and } \\
\text { manpower } \\
\text { (Rs./ha) }\end{array}$} & \multicolumn{2}{|c|}{$\begin{array}{l}\text { Cost of seed } \\
\text { (Rs./ha) }\end{array}$} & \multirow[t]{2}{*}{$\begin{array}{c}\text { Total } \\
\text { input cost } \\
\text { (Rs./ha) }\end{array}$} & \multirow{2}{*}{$\begin{array}{l}\text { Cost of } \\
\text { produce } \\
\text { (@ Rs. } \\
\text { 1400/q) } \\
\text { (Rs./ha) }\end{array}$} & \multirow[t]{2}{*}{$\begin{array}{c}\text { Net } \\
\text { Return } \\
\text { (Rs./ha) }\end{array}$} & \multicolumn{2}{|c|}{$\begin{array}{c}\text { Benefits of use of } \\
\text { dibbler over } \\
\text { khurpi (Rs./ha) }\end{array}$} \\
\hline & & $\begin{array}{l}\text { Seeding } \\
\text { with } \\
\text { khurpi }\end{array}$ & $\begin{array}{l}\text { Seeding } \\
\text { with } \\
\text { dibbler }\end{array}$ & & & & $\begin{array}{c}\text { Flat } \\
\text { sowing }\end{array}$ & $\begin{array}{c}\text { Bed } \\
\text { planting }\end{array}$ \\
\hline $\mathbf{T}_{1}$ & 6005.00 & 3000.00 & & 9005.00 & 131250.00 & 122245.00 & & \\
\hline $\mathbf{T}_{2}$ & 2784.00 & & 4537.00 & 7321.00 & 136416.00 & 129095.00 & 6850.00 & \\
\hline $\mathbf{T}_{\mathbf{3}}$ & $8005.00 *$ & 3000.00 & & 11005.00 & 146902.00 & 135897.00 & & \\
\hline $\mathbf{T}_{4}$ & 8784.00* & & 4205.00 & 12989.00 & 158536.00 & 145547.00 & & 9650.00 \\
\hline
\end{tabular}


Field capacity and cost of use of manually operated planting equipments and implements

The field capacity of equipments has direct bearing on their cost of use on area basis and thus, the cost of use of planting equipment such as khurpi and double fork dibbler were calculated on hectare basis and the same has been presented in Table 3. On observation of data, it is obvious that cost of use of planting equipment (khurpi) was maximum (Rs. 6005/-) in treatment $T_{1}$ followed by the treatment $T_{4}$ (5034/-), where dibber was used on bed.

In treatment $T_{3}$, khurpi was used for planting maize seeds on bed and the cost of use was found to be Rs. 4255.00. The minimum cost of planting was recorded in treatment $\mathrm{T}_{2}$ (Rs. 2784/-) in which maize seeds were planted in flat with the help of dibbler.

The data presented as above highlights the fact that the use of 'dibbler' had increased the total output of the manual labour in comparison to 'khurpi' in flat planting. There was a saving of 13 mandays in treatment $T_{2}$ compared to treatment $T_{1}$ and therefore, a saving of Rs. $3250 /$ - as labour cost due to use of dibbler in place of khurpi was recorded.

In bed planting, as the manual labour had to move along the furrow and across the bed, the field capacity of dibbler in treatment $\mathrm{T}_{4}$ had got reduced in caparison to 'khurpi' in treatment $\mathrm{T}_{3}$. In flat planting, it was easy and comfortable for the labour to move forward with dibbler and that had accounted to higher field capacity of dibbler in comparison to the 'khurpi'.

However, in treatment $T_{3}$, due to height of bed, the labour found easy to work in standing position with khurpi by slightly leaning forward and that had accounted to increased field capacity of khurpi on bed as comparison to the flat fields, where, the labour was moving forward in sitting position.

\section{Economics of cultivation}

Economics of cultivation of Rabi maize (Hybrid, Shaktiman-5) under different treatments has been presented in Table 4 .

Data recorded in table 4, shows that treatment $\mathrm{T}_{4}$ was highly economical with net return of Rs. 145547/- followed by treatment $\mathrm{T}_{3}$ (Rs. 135897/-) and $\mathrm{T}_{2}$ (Rs. 129095/-). The treatment $\mathrm{T}_{1}$ registered lowest return of Rs.122245/-. Obviously, bed planting system had its own advantage in comparison to the flat planting methods. Even on comparison between treatments $T_{1}, T_{2}$ and $T_{3}, T_{4}$, it is found that the use of dibbler gives more benefit in comparison to planting of maize by khurpi. A net benefit of Rs. 6850/- and Rs. 9650/- were registered with use of double fork dibbler in comparison to khurpi both for flat planting as well as bed planting conditions, respectively. The benefit with use of dibbler under flat planting condition was because of uniformity in dropping seed at proper depth and also due to placement of fertilizer closer to the seed. However, in case of bed planting condition, the benefits of use of dibbler coupled with benefits of bed planting system were found responsible for enhancement of benefits by Rs. 2800/- in treatment $\mathrm{T}_{4}$ as compared to treatment $T_{2}$. A general trend was observed that $40-50 \%$ more seed was required with use of dibbler both in treatment $\mathrm{T}_{4}$ (bed planting) and treatments $\mathrm{T}_{2}$ (flat planting), respectively. The over seeding with use of dibbler was because of construction of metering system, which allows dropping of more than one seed of lower size per stroke.

It has been concluded that the planting methods showed a positive correlation on growth and yield of maize crop. Bed planting was found to be better option for maize 
cultivation in comparison to flat planting. Further, use of dibbler provided better plant growth and yields both in flat as well as bed planting conditions. The dibbler was found to be an efficient hand tool for planting maize in comparison to khurpi and provided a net labour cost saving of Rs. 3250/- per hectare. However, benefits per hectare from use of dibbler in flat and bed planting conditions were recorded as Rs. 6850/- and Rs. 9650/-, respectively.

Use of double fork dibbler for planting maize is recommended both for flat as well as bed planting conditions in Rabi maize cultivation from economy and yield point of view. The use of dibbler on bed is found more yielding and economical due to the added benefits of increased fertilizer use efficiency, water use efficiency and better crop establishment facilitated by uniform distribution of roots of plant on bed.

\section{References}

Amin M., A. Razzaq, Rehmatullah and M. Ramzan. 2006. Effect of planting method, seed density and nitrogenphosphorous fertilizer level on sweet corn (Zea mays L.). J. Res. Sci. 17:8389.

Anonymous, 2015-16. Economic Survey, Finance Department, Government of Bihar.

Bakht J., M. Shafi, H. Rehman, Raziuddin and
S. Anwar. 2011. Effect of planting methods on growth, phenology and yield of maize varieties. Pak. J. Bot. 43:1629-33.

Bakht J., S. Ahmad, M. Tariq, H. Akbar and M. Shafi. 2006. Response of maize (Zea mays L.) to planting methods and fertilizer nitrogen. J. Agric. Bio. Sci. $1: 8-14$.

Butter G., S. Jalota, R. Mahey and N. Aggarwal. 2006. Early prediction of wheat yield in south-western Punjab sown by different planting methods, irrigation schedule and water quality using the CERES model. J. Agric. Physics. 6:46-50.

Naresh R. K., Gupta R. K., Satya P., Kumar A., Singh M., Mishra A. K. 2011. Permanent beds and rice-residue management for rice-wheat systems in the North West India. Int. J. Agric. Sci. 7(2):429-439

Ortega A. L., E. V. Mir and E. E. Rangel. 2008. Nitrogen management and wheat genotype performance in a planting system on narrow raised beds. Cereal. Res. Commun. 36: 343-52.

Verhulust N., A. Carrillo-Garca, C. Moeller, T. Richard, K. D. Sayre and B. Govererts. 2011. Conservation agriculture for wheat based cropping systems under gravity irrigation; increasing resilience through improved soil quality. Plant Soil. 340: 467-79.

\section{How to cite this article:}

Subhash Chandra and Mritunjay Kumar. 2019. Effect of Different Planting Methods on Yield and Economics of Cultivation of Maize. Int.J.Curr.Microbiol.App.Sci. 8(12): 1318-1324. doi: https://doi.org/10.20546/ijcmas.2019.812.160 